\title{
Detection of dry season anomaly using radiosonde data during intensive observation period (IOP) in 2017
}

\author{
Rini Mariana S. ${ }^{1, *}$, Ibnu Athoillah ${ }^{1}$, Rahmawati Syahdiza ${ }^{1}$, Erwin Mulyana ${ }^{1}$, Findy Renggono ${ }^{1}$, Tri Handoko S. ${ }^{1}$, Jon \\ Arifian $^{1}$, Budi Harsoyo ${ }^{1}$, Edvin Aldrian ${ }^{1}$, Yunus Subagyo $S^{2}$ \\ ${ }^{1}$ National Laboratory for Weather Modification Technology, Agency for The Assesment and Application of Technology, GEOSTECH \\ (820), PUSPIPTEK Area, Serpong, South Tangerang 15314, Indonesia \\ ${ }^{2}$ Agency of Meteorology Climatology and Geophysics, Kemayoran, Central Jakarta, Indonesia
}

\begin{abstract}
In the period between July - August 2017, Indonesia experiences drought which was caused by The Australian Monsoon wind. Radiosonde data obtained from launches conducted at the Palembang Meteorological Station during the IOP of 17 July - 16 August 2017 and those from cities that represents monsoon area (Pangkalpinang, Jakarta, and Surabaya) were also added to analyze the connection between Australian monsoon and precipitation in Indonesia. During IOP, the Australian Monsoon Index (AUSMI) is weaker than during normal conditions. Australian Monsoon index is normally around $6 \mathrm{~m} / \mathrm{s}$. Here, The Australian Monsoon Index chart shows a sinusoidal pattern in which during the peaks and troughs of the index there were drought anomalies in the aforementioned cities. In addition, medium to heavy rainfall also occurs during the Australian Monsoon index peaks and troughs. That conditions are affected by MJO and local influence. When MJO is a negative anomaly, AUSMI Index can be at peak or at the troughs. During the drought anomalies in all of the four cities, moisture profile at the surface to $6000-8000 \mathrm{~m}$ is very wet $(65-100 \%)$ with vertical wind profile dominated by the southeasterly-southerly direction.
\end{abstract}

\section{Introduction}

Indonesia's location that lies within the tropics has the capacity to build and produce complex systems. Understanding atmospheric dynamics over atmospheric vertical profiles in Indonesia is therefore urgently needed to better understand climate and climate processes for the entire region.

Upper air profile is usually measured by using radiosonde, which obtains some weather parameters data, i.e. air pressure, ambient temperature, relative humidity (RH), wind direction and velocity. These measurements were performed to study the character and dynamics of the measured atmosphere. Other weather parameters and indices could then be derived from these parameters. If measurements were conducted in many places within a large area and in a relatively long period, the data could also be used to study atmospheric characteristic in the surrounding region.

The upper air layer has both unique and distinctive characteristics. Upper air observations have a limited area and timescale compared to the processes that affect it [1] Most weather phenomena occur in the upper atmosphere, including the rise of the air parcel, the state when it becomes saturated, condensed, and finally falls as precipitations. The vertical structure and it's physical and dynamical processes is still a challenging area which can be explored further. Tools and equations have been used and developed for this purpose, from kites to aerological diagrams. A complete atmospheric description will show a better understanding of atmospheric conditions. Hence, it is necessary to observe the upper air layer to understand the condition of the atmosphere in the actual state.

Location of Indonesia is flanked by two oceans and two continents causing Indonesian Maritime Continent (IMC) territory being strongly affected by The Asian-Australian monsoon. A book in [2] defines the monsoon area as encompassing regions with January and July surface circulation which is enclosed between the area of $35 \mathrm{~N}$ and $25 \mathrm{~S}$ and between $30 \mathrm{~W}$ and $170 \mathrm{E}$. A series in a book [3] stated that monsoon is a reversal of seasonal wind patterns caused by temperature gradients between land and sea. These major reversals in the seasonal wind regimes only occurs over (1) India and South-East Asia, (2) northern Australia, and (3) West and central Africa. These three regions constitute the major monsoons of the global circulation.

Monsoon area covers almost all of the tropical area with nearly $60 \%$ of world's population, dominated by third world countries. The socio-economic life of people in this area revolves and depend on the monsoon cycle. Understanding monsoon variability will provide proper knowledge that can be used to maximize the benefit of monsoon rainfall and reduces the impact of extreme events.

In a simple way, the monsoon mechanism can be regarded as a large-scale sea breeze with a seasonal period which is caused by different heat capacity that exists 
between an ocean and a continent. During summer, large land masses heated more rapidly and draw humid air from the ocean, the wind from the ocean with the centre of low pressure would then bring the moisture out over the warm lands. On the other hand, the continent becomes much cooler than the surrounding oceans during winter. The air flowing from the land out and then over the ocean would also bring cold and dry air. During summer in the Asian Continent, a low-pressure centre is formed in that area on the tropical land, while at the same time, Australian continent experiences winter, which makes the pressure in this area higher than those at the Asian Continent. As a result of the pressure differences, winds are moving from Australia to Asia while passing through the maritime continent. The cold, dry wind from Australia lead to dry season in Indonesia. On the contrary, when the Asian Continent experiences winter, the air will flow from Asia to Australia. The winds of the Asian continent bring dry and cold air from the land but since it travelled a long way through the vast Pacific Ocean, the wind then becomes moist and humid air which contains a lot of water vapour that drops in the Indonesian area which indicates the commencement of the rainy season. This cycle can then be distinguished as the dry season and the wet season. The dry season is influenced by the winter that occurs in various continents which brings cold and dry air [4]. In contrast, the wet season is influenced by summer with humid air.

There have been a large number of research related to monsoon spatial variations in Indonesia, Reference [5] shows distinctions of monsoon influences on climate response on a local scale and classified it into three climatic regions, i.e. Region $\mathrm{A}$, which is the southern and central part of Indonesia with monsoonal type precipitation; Region B, the north-western part of Indonesia with two precipitation peaks per year and is influenced by its position around the equator; and Region C, the Maluku region known as a local precipitation type. Journal article in [6] delineated Indonesia Maritime Continent area based on the rainfall variability into three different regions: i.e. SMP (Sumatra and Malay Peninsula area), SWO (Southwest Ocean Area) and CMC (Central Maritime Continent Area). Reference [7] stated that the southern part of the Indonesian main islands is influenced by The Australian summer monsoon. A journal [8] stated that area with the strongest association to Australian summer monsoon is in Lampung, Java, Southern Kalimantan and Makassar during the DJF (December, January, and February) period. All of the previous research results agree that the southern part of Indonesia consistently shows a strong response to the Australian summer monsoon. Monsoon impacts in a region can be shown through the monsoon indices. There are various types of monsoon indices that can be used to described monsoon conditions in related areas. Journal article of [9] indicates that the Australian Monsoon Index (AUSMI) can illustrate the variability of monsoonal rainfall in the northern and Maritime Continental regions.

Research related to the upper air structure during monsoon was conducted by [10] using EAR (Equatorial Atmospheric Radar) data for a duration of 5 years (April 2002-April 2006) in Kototabang to study the atmospheric vertical profile in equatorial areas. The results showed that there was a significant difference between the wet and dry season. Monsoon oscillations were seen at an altitude of 8$18 \mathrm{~km}$, while at $2-7 \mathrm{~km}$ altitude there was no sign of monsoon oscillation. Furthermore, reference [11] uses 5 years (2010-2014) of radiosonde data at 11 stations which spread across Indonesia, Malaysia and Singapore. The results showed the periodicity of zonal wind components in the lower troposphere (below $5 \mathrm{~km}$ ) in the Jakarta, Surabaya, Makassar, Ambon and Merauke radiosonde stations. On the contrary, same as [10], [11] also found that the seasonal periodicity is not apparent in Medan, Padang, Singapore, Kuching, Menado and Biak stations.

This research goal is to detect dry anomalies during the Intensive Observation Program (IOP) activity in Palembang by using the Pangkalpinang, Jakarta and Surabaya radiosonde stations data as a comparison.

\section{The material and method}

The main data used in this research are radiosonde data, daily rainfall data, and $850 \mathrm{mb}$ zonal wind data which were obtained during an Intensive Observation Period (IOP) in Palembang from July 17th to August 16th, 2017. The target locations of this research are Palembang, Pangkalpinang, Jakarta and Surabaya (see Fig. 1.).

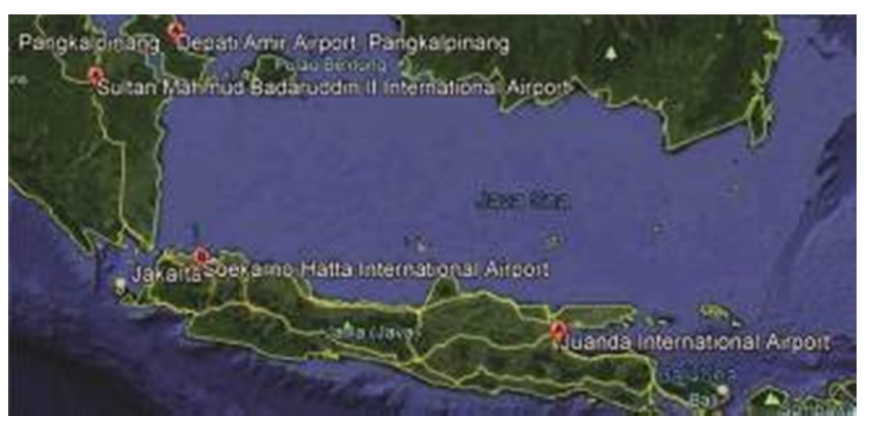

Fig. 1. The target locations of this research

The radiosonde data used were data from Pangkalpinang, Jakarta and Surabaya which were taken from http://weather.uwyo.edu/upperair/sounding.html, while the radiosonde data Palembang was obtained from launches at the Palembang station during the IOP. The radiosonde data used were obtained from launches conducted at 00 and 12 UTC, every day. The format of radiosonde data in the form of ASCII can be directly viewed in terms of its contents and it can also be processed easily by using the GRADS software to create cross-section analysis of relative humidity and vertical wind profile.

Rainfall data was obtained from ogimet.com. Daily rainfall data use rainfall data from The Sultan Mahmud Badaruddin II Airport in Palembang, Depati Amir Airport in Pangkalpinang, Soekarno Hatta International Airport in Cengkareng Jakarta and also the Juanda International Airport in Surabaya.

In addition, the $850 \mathrm{mb}$ zonal wind data is used to view the Australian Monsoon Index (AUSMI). The data was obtained from http://apdrc.soest.hawaii.edu/ and https://www.esrl.noaa.gov/psd/data/gridded/. According [9], the AUSMI can be obtained from the following equation: 


$$
\operatorname{AUSMI}=\mathrm{U}_{850}\left(110^{\circ}-130^{\circ} \mathrm{E}, 15^{\circ}-5^{\circ} \mathrm{S}\right)(1)
$$

Where :

$$
\begin{aligned}
& =\text { Australian Monsoon Index, } \\
& =\text { zonal wind component at } 850 \mathrm{mb}(\mathrm{m} / \mathrm{s}) .
\end{aligned}
$$

The AUSMI calculations were performed by using $850 \mathrm{mb}$ of zonal wind data averaged over the area between $110^{\circ} \mathrm{E}-130^{\circ} \mathrm{E}$ and $15^{\circ} \mathrm{S}-5^{\circ} \mathrm{S}$ from $1972-2015$ and compared to $850 \mathrm{mb}$ zonal wind data in 2017 .

This paper uses profile wind data from Radiosonde to detection Australia Monsoon in Palembang, Pangkalpinang, Jakarta, Surabaya and AUSMI index to detection MJO. That are parameters that give affect the drought anomalies in the four cities.

\section{Results and discussion}

Palembang, Pangkalpinang, Jakarta and Surabaya are categorized as the monsoonal area with minimum rainfall occurring during the July-August period [5]. This theory was proven by IOP data (Intensive Observation Period) obtained on 17 July - 16 August 2017 from Palembang, Pangkalpinang, Jakarta and Surabaya which shows a decrease in rainfall intensity during the period of observation. Australian Monsoon is one of the main causes of the decrease in rainfall intensity. Figure 2 shows the profile meridional and zonal winds in Palembang, Pangkalpinang, Jakarta and Surabaya on IOP Period. At the time of Australian monsoon, that cities have meridional winds with positive value (wind direction from south to North) and zonal winds with negative value (wind direction from east to west).
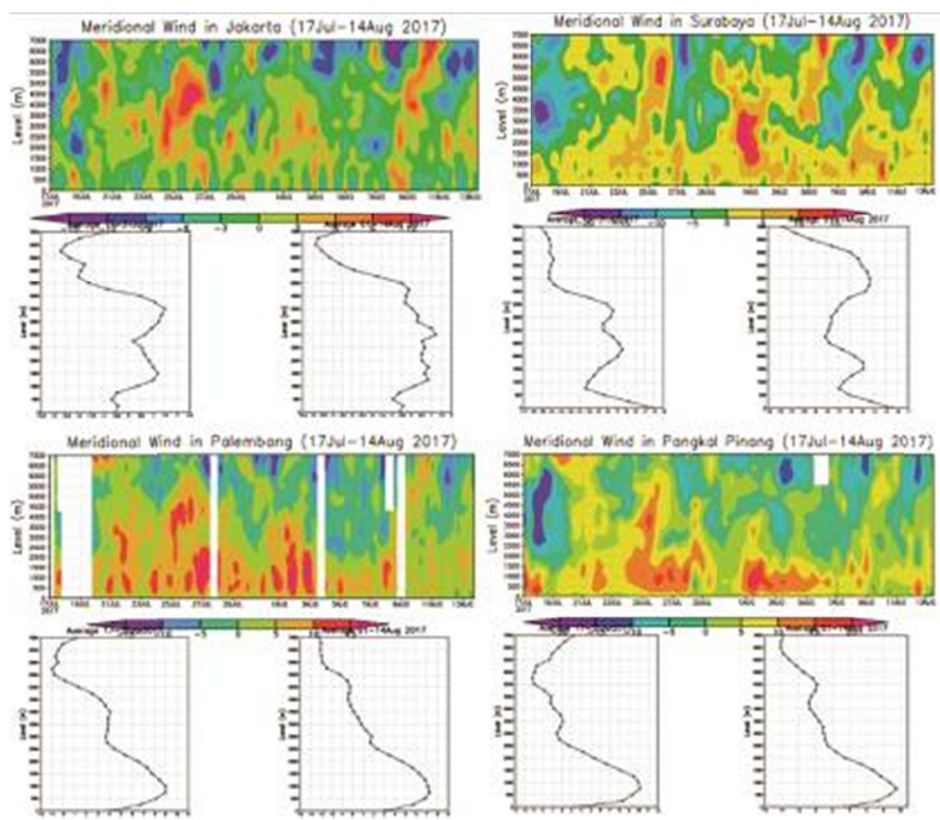

Fig. 2. Profile meridional wind (left) and zonal wind (right) at IOP period from observation data (RASON) in Palembang, Pangkalpinang, Jakarta and Surabaya

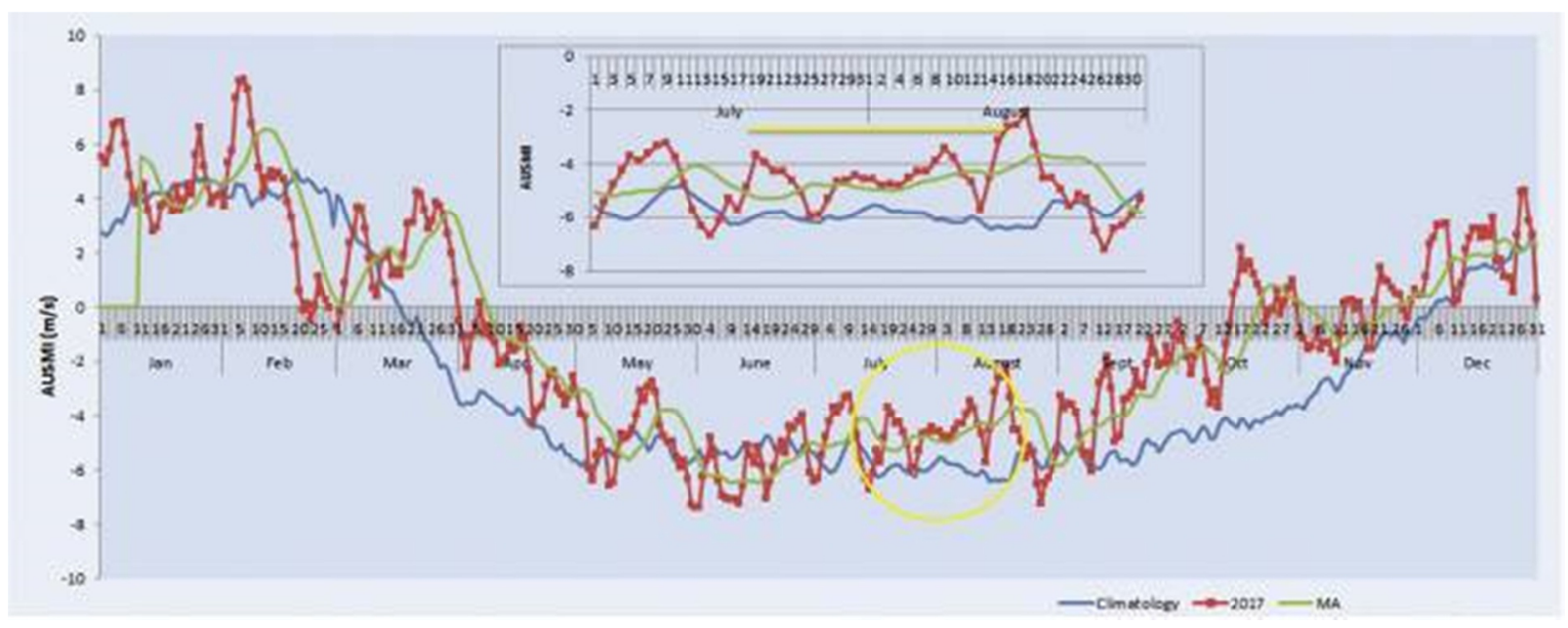

Fig. 3. Australian summer monsoon index (AUSMI) historical (climatologies) chart from July-August 2017, and its moving average in the year 2017 

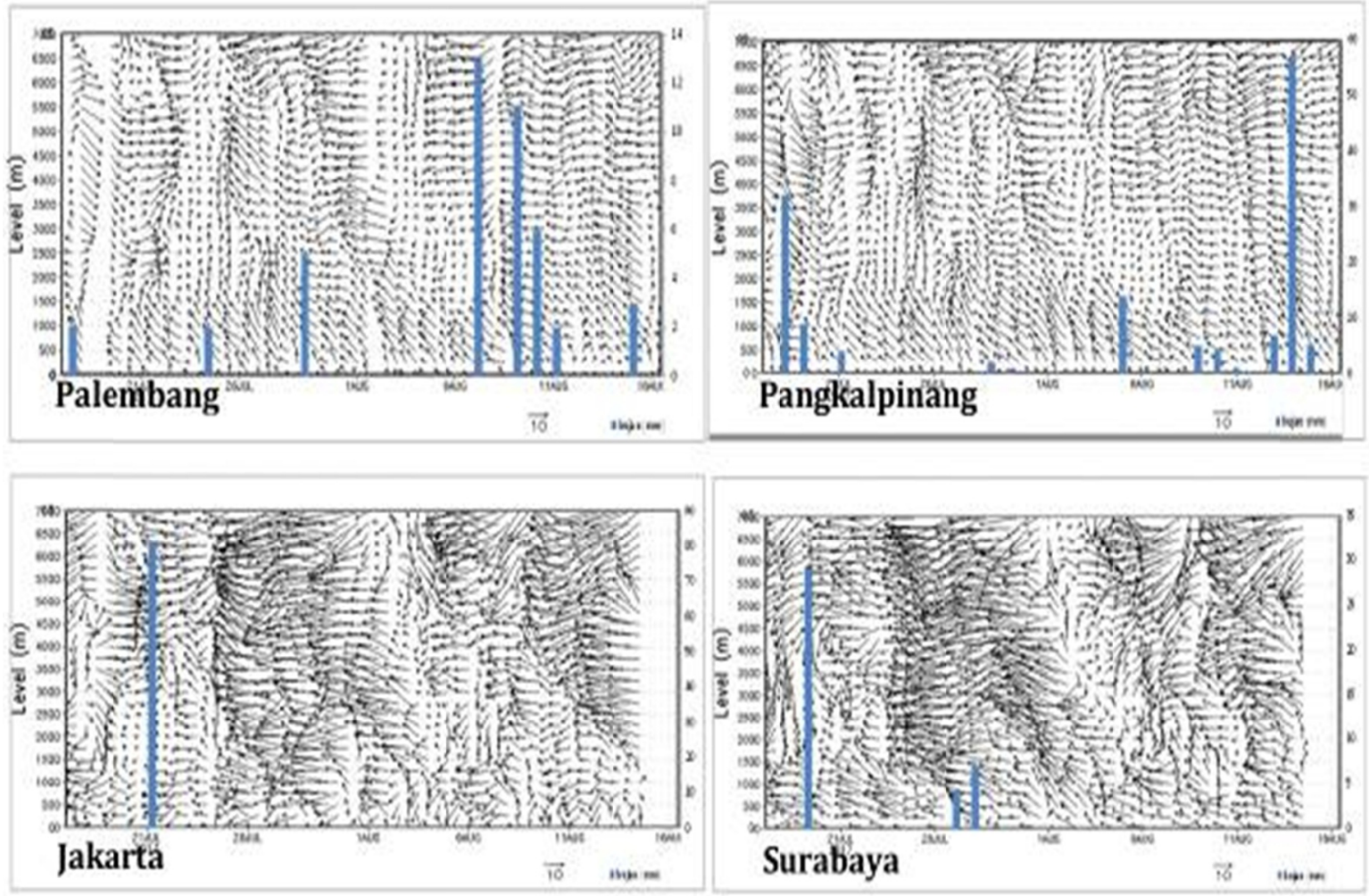

Fig. 4. Wind profile in the four cities (Palembang, Pangkalpinang, Jakarta and Surabaya) and their rainfall chart from 17 July - 16 August 2017 (source : Palembang IOP data, http://weather.uwyo.edu/upperair/sounding.html and http://www.ogimet.com/)
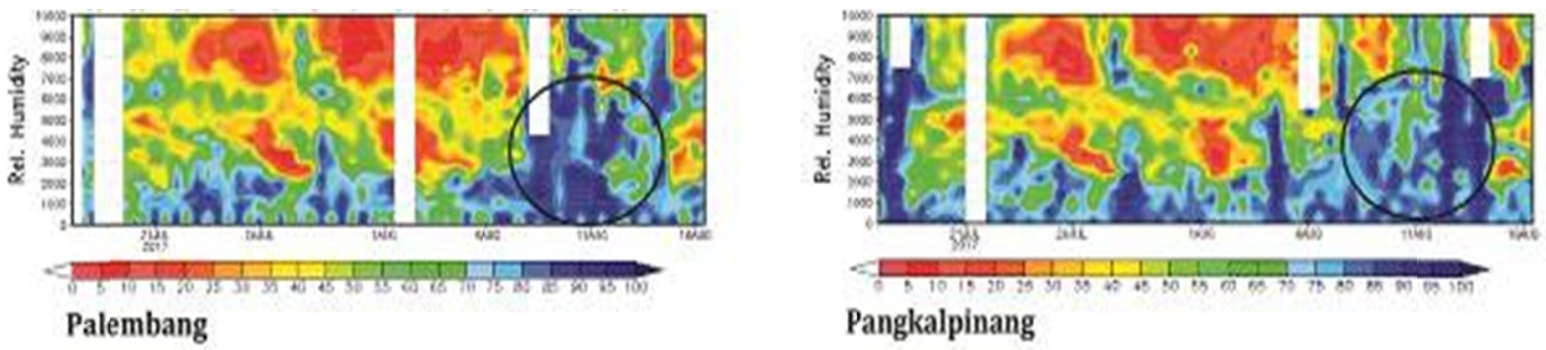

Pangkalpinang
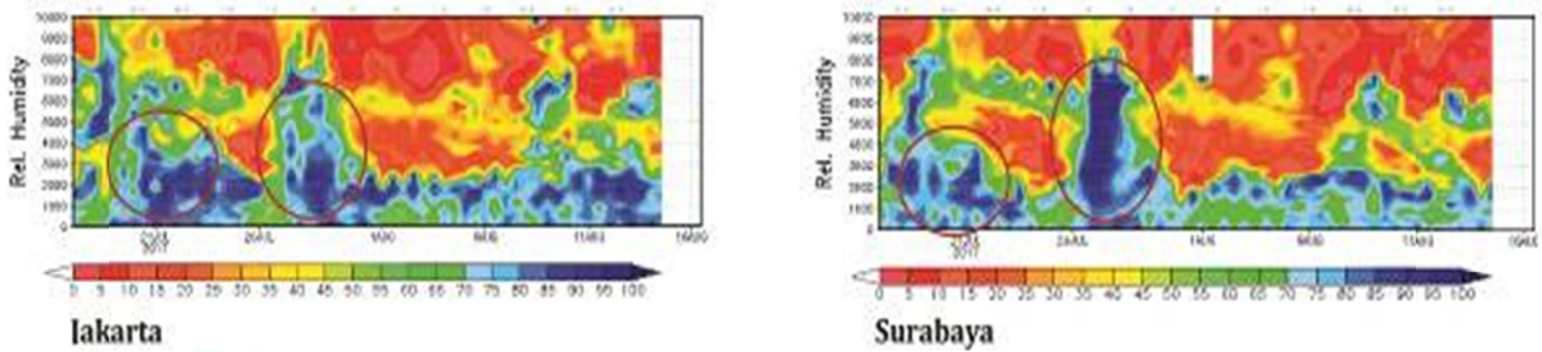

note : rainfall event in Jakarta and Surabaya
rainfall event in Palembang and Pangkalpinang

Fig. 5. Relative humidity profile in Palembang, Pangkal Pinang, Jakarta and Surabaya (source : Palembang IOP data, while those of Pangkalpinang, Jakarta and Surabaya were obtained from http://weather.uwyo.edu/upperair/sounding.html) 
Strong and weak influence of Australian Monsoon in causing rain in Indonesia, especially in these four cities, can be seen from the AUSMI (Australian Summer Monsoon Index) value. AUSMI was obtained from $850 \mathrm{mb}$ zonal wind data on 110$130 \mathrm{E}$ and $15 \mathrm{~S}-5 \mathrm{~S}$. Figure 3 shows the AUSMI at 2017, where climatological data (1972 - 2015) were obtained from the website: http://apdrc.soest.hawaii.edu/projects/monsoon/dailydata.html\#aus, while the $850 \mathrm{mb}$ zonal wind data throughout 2017 is retrieved from the website: https://www.esrl.noaa.gov/psd/data/gridded/. The AUSMI during the period July-August 2017 is dominantly below normal, which indicate a weak AUSMI. A weak AUSMI shows little influence toward the rainfall reduction in the four observed cities. Although the monsoon index was weak from July-August 2017, the monthly rainfall data from TRMM showed that the condition of the four cities remained below normal.

This indicates that during the IOP period, these four cities experienced the dry season. However, there were several days during the IOP that highintensity rain was observed. The observed highintensity rains were recorded in all of the four areas. The precipitation anomaly which happened during this period is referred to as drought anomalies in this paper. The rainfall in those areas was indicated to be higher than normal condition. Also, the AUSMI during IOP 2017 which started from July 17th to August 16th, 2017 formed a sinusoidal pattern that has two peaks and two troughs. These sinusoidal peaks occurred on 18-19 July 2017 and 08-10 August 2017, while the sinusoidal troughs occurred on July 25-27, 2017 and August 12-14, 2017.

Compared to the daily rainfall data on those date range at the time AUSMI reach the peaks and troughs, it was found that moderate to heavy rainfall occurred in all of the four areas. While from the [12] report on Madden - Julian Oscillation: Recent Evolution, Current Status and Prediction, a negative OLR anomaly was observed in South Sumatra (100$1050 \mathrm{E})$ during the peaks and troughs of the AUSMI index (17-19 July 2017, 12-14 August 2017 and 1418 August 2017). The negative OLR indicates an enhanced convection in the Palembang and Pangkalpinang area which could, in turn, enhance the occurrence of high-intensity rain.

Figure 4 shows wind profiles in Palembang, Pangkalpinang, Jakarta and Surabaya and rainfall graphs in the four cities. Wind profile conditions in the four cities have a relatively similar direction which is dominated by the Southeast - South direction, with wind speed in Jakarta and Surabaya being greater when compared to wind speed in Palembang and Pangkalpinang. Also, the wind at 850 $\mathrm{mb}( \pm 1,500 \mathrm{~m})$ has a varying direction. The wind at $850 \mathrm{mb}$ in Palembang is predominantly from the southeast with a speed of $<10 \mathrm{~m} / \mathrm{s}$, in Pangkalpinang, the wind is predominantly from the southeast with a speed of $>10 \mathrm{~m} / \mathrm{s}$, while in Jakarta and Surabaya the wind is predominantly from the east with a speed of $>$ $10 \mathrm{~m} / \mathrm{s}$. Based on the data from the website: http://www.ogimet.com/, from July 17 to August 16 2017, drought anomalies in Palembang and Pangkalpinang occur frequently when compared with Jakarta and Surabaya. This is due to the greater abundance of water vapour supply in Palembang and Pangkalpinang when compared to those in Jakarta and Surabaya. At the time of the drought anomaly, wind speed in the four cities does not exceed $10 \mathrm{~m} / \mathrm{s}$. This so as not to interfere the growth of convective clouds forming rain.

The condition of the upper air profile in four cities (Palembang, Pangkalpinang, Jakarta and Surabaya) in the period of July 17 - August 16, 2017, can be seen in Figure 5. Similar to the wind profile, the air profile condition of Palembang is relatively similar to the air profile over Pangkalpinang. While the upper air profile of Jakarta is relatively similar to the air condition over Surabaya. The condition of air humidity profile (RH) in Jakarta and Surabaya is relatively dry when compared to the relative humidity profile (RH) in Palembang and Pangkalpinang. During this period, relative humidity $(\mathrm{RH})$ in Jakarta and Surabaya ranges from $5-100 \%$, while relative humidity $(\mathrm{RH})$ in Palembang and Pangkalpinang ranges from $15-100 \%$.

In addition, Palembang and Pangkalpinang experienced dry season anomalies or wetter condition with relative humidity profile of around $65-100 \%$ at the surface level and up to $7,000 \mathrm{~m}$, as compared to the humidity profile condition (RH) in Jakarta and Surabaya. When the humidity profile $(\mathrm{RH})$ from the surface to $6,000 \mathrm{~m}$ in Jakarta and Surabaya experienced dry season anomalies, the condition becomes wetter with $\mathrm{RH}$ profile dropping to around $60-100 \%$ when compared to the humidity profile in Palembang and Pangkalpinang. Figure 5 represents the humidity profile conditions of Palembang and Pangkalpinang. The black circles indicate rain events during the period of 6-15 August 2017. While the humidity profile in Jakarta and Surabaya at the time of rain events (period 20-21 July 2017 and 27-30 July 2017) is represented by the red circle.

\section{Conclusion}

\subsection{Conclusion}


This paper shows drought anomalies when Australia Monsoon in Palembang, Pangkalpinang, Jakarta and Surabaya use Radiosonde data, rainfall data and AUSMI data. Drought anomalies have occurred if AUSMI index is its peak and troughs condition. That drought anomaly indicated by heavy-intensity rain on several days. That conditions are affected by MJO and local influence. But during IOP Period the drought anomalies are influenced by MJO. From this study, We know that when MJO is a negative anomaly, AUSMI Index can be at peak or at the troughs.

\subsection{Further suggestion}

1. Longer data analysis required to be able to conclude the draw a relation between the peaks and troughs of the AUSMI index to drought anomalies in the four cities.

2. Further review of the relation between the Australian Monsoon index to MJO and its effect on rain in Indonesia should be conducted.

\section{References}

1. Pettersen S., Weather Analysis and Forecasting, 2nd edition, Vol. 1, New York: McGraw-Hill. 1956

2. Ramage, C. S., Monsoon Meteorology, Academic Press, 1971

3. Slingo, J., Monsoon Overview, Encyclopedia of Atmospheric Science, Holton, J. Pyle, J., and Curry, J., London: Academic Press, pp. 13651370, 2003

4. Yulihastin, E., Difference in Rainfall Phase and Monsun Wind in Indonesia Based on TRMM Satellite Data, National Proceeding of LAPAN, 2010

5. Aldrian, E., and Susanto, R. D., Identification of Three Dominant Rainfall Regions within Indonesia and Their Relationship to Sea Surface Temperature, International Journal Climatology, 23, pp. 1435-1452, 2003

6. Chang, C. -P., Wang, Z., Ju, J., and Li, T., On the Relationship Between Western Continent Monsoon Rainfall and ENSO during Northern Winter, Journal of Climate, 17, pp. 665-672, 2004

7. Zhang, S. and Wang, B., Global Summer Monsoon Rainy Seasons, International Journal of Climatology, 28, pp. 1563-1578, 2008

8. Nuryanto, D. E., The Linkage Between IndoAustralian Monsoons and Spatial Variablility in
Seasonal Rainfall in Indonesia's Maritime Continent Spatially Based on Results of TRMM Satellite Data Analysis, Meteorology and Geopgysics Journal, 13, pp. 91-102, 2012

9. Kajikawa, Y., Wang, B., and Yang, J., A multitime scale Australia monsoon index, Int. J. Climatol, 30, pp. 1114-1120, 2010

10. Azteria, V., Effendy, S., and Hermawan, E., Utilization of Equatorial Atmosphere Radar (EAR) Data in Assessing the Occurrence of Monsoons in the Western Region of Indonesia, J. Agromet, 22, pp. 160-172, 2008

11. Syaifullah, D., Analysis of Upper Air Condition of Indonesia Territory, Meteorology and Geophysics Journal, 18, pp. 1-12, 2017 CPCNCEP. Madden-Julian Oscillation: Recent Evolution, Current Status and Predictions, Oct. 2017. 